\title{
Aplikasi Expert System Berbasis Fuzzy Logic untuk Mendiagnosa Gaya Belajar Dominan Mahasiswa
}

\author{
${ }^{1}$ Hardianto Rahman, ${ }^{2}$ Nurjannah, ${ }^{3}$ Syarifuddin \\ 1,2,3 Tadris Matematika, Institut Agama Islam Muhammadiyah Sinjai, Indonesia \\ 12antoks.hr@gmail.com, ${ }^{2}$ nurjannah310807@gmail.com, ${ }^{3}$ hidayatullahsyarif05@gmail.com
}

\section{INFO ARTIKEL}

Riwayat Artikel:

Diterima: 19-08-2019

Disetujui: 01-10-2019

\section{Kata Kunci:}

Aplikasi Online;

Expert System;

Fuzzy logic;

Gaya Belajar.

\section{Keywords:}

Online Application;

Expert System;

Fuzzy logic,

Learning Style.

\begin{abstract}
ABSTRAK
Abstrak: Tujuan dari penelitian ini untuk mengembangkan produk aplikasi expert system yang berbasis fuzzy logic untuk mendiagnosa gaya belajar dominan. Penelitian ini dirancang dengan menggunakan model ADDIE (Analysis, Design, Development, Implementation, Evaluation). Hasil penelitian yang diperoleh yaitu: aplikasi pendiagnosa gaya belajar dominan dinyatakan memenuhi kevalidan dan keefektifan. Hasil ini diperoleh setelah dilakukan uji validitas oleh para ahli yang terdiri dari validasi instrumen berupa pertanyaan tentang indikator masing-masing gaya belajar yang keseluruhan aspek berada pada kategori valid yakni 3,32 untuk aspek visual, 3,18 untuk aspek auditorial dan 3,32 untuk aspek kinestetik. Sementara untuk validasi aplikasi yang berada pada kategori sangat valid dengan nilai rata-rata validator adalah 3,52. Aplikasi ini dikatakan efektif digunakan berdasarkan penilaian mahasiswa tentang keefesienan aplikasi, tampilan dan penggunaan bahasa yang berada pada kategori sangat efektif dengan rata-rata sebesar 3,57 dengan persentase $89 \%$ sehingga aplikasi ini dikatakan layak digunakan untuk mendiagnosa gaya belajar dominan seseorang.
\end{abstract}

\begin{abstract}
The purpose of this research is to develop an expert system application product based on fuzzy logic to diagnose the dominant learning style. This study was designed using the ADDIE model (Analysis, Design, Development, Implementation, Evaluation). The result study was obtained: application for diagnosing dominant learning styles is stated to fulfill validity and effectiveness. These results were obtained after the validity test by experts consisted of instrument validation in the form of questions about the indicators of each learning style whose overall aspects were in the valid category namely 3.32 for the visual aspect, 3.18 for the auditory aspects and 3.32 for kinesthetic aspects. While for application validation which is in a very valid category with an average validator value is 3.52. This application is said to be effective to use based on student assessment of application efficiency, display and use of language that is in a very effective category with the average student rating of 3.57 with a percentage of $89 \%$ so that this application is can be used to diagnose one's dominant learning style.
\end{abstract}

\section{A. LATAR BELAKANG}

Gaya belajar menjadi hal paling mendasar bagi peserta didik karena dengan mengetahui gaya belajar, mereka akan dengan mudah menyerap, mengolah dan mengatur informasi yang diterima. Pengetahuan akan gaya belajar setiap peserta didik sangat penting agar mereka bisa menggunakannya secara efektif saat proses belajar mengajar berlangsung.

Salah satu dari tiga faktor utama yang selayaknya dilakukan analisis pembelajaran oleh seorang guru sebelum melakukan pembelajaran adalah pemetaan gaya belajar (Smaldino, Lowther, \& Russel, 2013). Hal ini menunjukkan bahwa begitu pentingnya mengetahui gaya belajar dalam dunia Pendidikan.

Gaya belajar secara simultan/bersama-sama maupun secara terpisah dapat mempengaruhi prestasi belajar (Luji Bire, Geradus, \& Bire, 2014). Berdasarkan pendapat tersebut, terlihat jelas bahwa gaya belajar memang sangat penting untuk diketahui untuk memperoleh hasil belajar yang baik. Oleh karena itu, sangat penting bagi pendidik untuk 
membantu peserta didik agar mereka tahu gaya belajar yang sesuai dengan diri mereka masingmasing.

Sejalan dengan pendapat tersebut, Hartati (2013) dan Nurhidayah (2015) mengemukakan bahwa gaya belajar merupakan cara seseorang untuk menyerap, mengatur dan mengolah bahan informasi atau bahan pelajaran (Hartati, 2013), (Nurhidayah, 2015). Dalam merespon stimulus/informasi, ada siswa yang senang merespon informasi sendiri, tetapi ada pula siswa yang merespon informasi secara bersamasama membentuk kelompok. Siswa yang mempunyai gaya belajar mandiri berusaha menyelesaikan masalahnya sendiri. Dengan demikian siswa tersebut dapat lebih termotivasi dalam belajar sehingga hasil belajarnya pun akan lebih baik (Widayanti, 2013), (Fuad, 2016).

Terdapat tiga modalitas (type) dalam gaya belajar yaitu visual, auditorial, dan kinestetik (DePorter \& Hernacki, 2015). Gaya belajar visual (visual learner) adalah gaya belajar dimana gagasan, konsep, data dan informasi lainnya dikemas dalam bentuk gambar dan teknik (Luji Bire et al., 2014). Manusia dengan gaya belajar visual akan belajar dengan efektif apabila ia menggunakan penglihatannya untuk menyerap informasi. Sedangkan gaya belajar auditif (auditory learner) adalah suatu gaya belajar dimana siswa belajar melalui mendengarkan. Manusia dengan gaya belajar auditory akan mengandalkan kesuksesan dalam belajarnya melalui telinga (indra pendengarnya) (Sari, 2014). Sedangkan gaya belajar kinestetik (tactual learner) adalah gaya belajar dimana siswa belajar dengan cara melakukan, menyentuh, merasa, bergerak, dan mengalami. Anak dengan gaya belajar kinestetik mengandalkan belajar melalui bergerak, menyentuh, dan melakukan tindakan (Rusman, 2012).

Gaya belajar visual menitikberatkan pada indra penglihatan sehingga peserta didik yang memiliki gaya belajar ini lebih cenderung menyukai proses pembelajaran yang melibatkan gambar dan segala sesuatu yang berhubungan dengan penglihatan. Gaya belajar auditorial atau lebih dikenal dengan gaya belajar audio, yakni gaya belajar yang menggunakan indra pendengaran. Sedangkan gaya belajar kinestetik yakni gaya belajar yang mengharuskan adanya gerakan atau praktek saat proses belajar mengajar berlangsung. Peserta didik yang memiliki gaya belajar kinestetik cenderung tidak bisa duduk tenang dalam kelas karena pada dasarnya mereka lebih senang mencoba hal yang dipelajari daripada hanya melihat ataupun mendengar teorinya saja. Pada dasarnya, setiap individu memiliki ketiga gaya belajar ini, yakni visual, auditorial, dan kinestetik hanya saja biasanya ada gaya yang lebih mendominasi gaya yang lain (Khoeron, Sumarna, \& Permana, 2016), (Yurizki, Halim, \& Melvina, 2017), (Astika, 2018).

Berdasarkan hasil observasi dan interview di lapangan, tim peneliti menemukan onformasi bahwa kurangnya pemahaman tentang gaya belajar banyak terjadi di lapangan. Hal ini terjadi pula pada mahasiswa Institut Agama Islam Muhammadiyah (IAIM) Sinjai Program Studi Tadris Matematika. Pada dasarnya, mahasiswa-mahasiswi yang menjalani studi di Tadris Matematika memiliki kemampuan yang berbeda-beda jika ditinjau dari segi kecepatan dalam memproses informasi. Sebagian dari mereka adalah mahasiswa yang mampu menyerap materi dengan cepat dan sebagian lagi membutuhkan proses yang sedikit lebih lama dari yang lain. Jika diamati lebih dalam, hal yang menjadi kendala perbedaan kemampuan ini tidak lain adalah kurangnya pemahaman mereka tentang gaya belajar dominan yang dimiliki sehingga mereka tidak mampu menyesuaikan dengan materi yang dipelajari.

Dengan mengetahui gaya belajar dominan, diharapkan nantinya mahasiswa dapat menggunakannya sebagai acuan sehingga dapat meningkatkan kecepatan dalam menerima materi kuliah yang nantinya akan berdapak positif terhadap prestasi belajarnya. Hal ini sejalan dengan pendapat yang menyatakan bahwa mengenali gaya belajar sendiri, belum tentu membuat seseorang menjadi lebih pandai, tetapi dengan mengenal gaya belajar seseorang akan dapat menentukan cara belajar yang lebih efektif (Wahyuni, 2017).

Terdapat beberapa penelitian yang mengkaji tentang gaya belajar, contohnya penelitian yang dilakukan oleh Bire, A. L., Geradus, U., \& Bire, J., yang meneliti tentang "Pengaruh Gaya Belajar Visual, Auditorial, dan Kinestetik Terhadap Prestasi Belajar Siswa". Fokus penelitian ini adalah untuk mengetahui ada tidaknya pengaruh gaya belajar terhadap prestasi belajar siswa. Hasil penelitiannya menunjukkan bahwa ada pengaruh simultan atau 
non simultan antara gaya belajar dengan prestasi belajar siswa (Luji Bire et al., 2014). Setelah itu, tidak ada tindak lanjut terhadap gaya belajar tersebut.

Penelitian lain dilakukan oleh Rais (2015) yang meneliti tentang "Pengaruh Penggunaan Multimedia Presentasi Berbasis Prezi dan Gaya Belajar Terhadap Kemampuan Mengingat Konsep". Penelitian ini bertujuan untuk melihat pengaruh penggunaan Prezi dan gaya belajar terhadap kemampuan mengingat konsep dengan membandingkan antara penggunaan Prezi dengan penggunaan media Power Point dalam menyampaikan materi pembelajaran. Hasil penelitian menunjukkan bahwa ada pengaruh positif antara penggunaan teknologi Prezi dan gaya belajar visual, audiotory dan kinestetik terhadap pemahaman konsep siswa (Rais, 2015).

Kedua penelitian tersebut sama-sama mengkaji tentang gaya belajar akan tetapi hanya sebatas melihat apakah ada pengaruh gaya belajar terhadap prestasi belajar dan apakah ada pengaruh Prezi dan gaya belajar terhadap pemahaman konsep tanpa adanya tindak lanjut terhadap gaya belajar tersebut Oleh karena itu, dibutuhkan suatu penelitian yang akan mengkaji tentang upaya tindak lanjut untuk mengetahui bagaimana cara mendiagnosa gaya belajar peserta didik.

Selama ini, apabila terdapat penelitian yang berkaitan dengan gaya belajar, maka hal yang dilakukan oleh peneliti adalah mengelompokkan subjek penelitian yang memiliki gaya belajar visual, audiotory dan kinestetik (VAK) dengan cara manual yakni dengan memberikan angket gaya belajar. Akan tetapi, seiring dengan berkembangnya teknologi, maka mengelompokan dengan cara manual seperti ini sudah tidak perlu lagi dilakukan.

Dengan memanfaatkan teknologi komputer serta fuzzy logic, maka dimungkinkan untuk membuat sebuah aplikasi expert system yang dapat membantu mengelomppokkan gaya belajar dominan dengan mudah. Logika samar atau fuzzy logic pertama kali diperkenalkan oleh Prof. Lotfi A. Zadeh pada tahun 1965. Dasar fuzzy logic adalah teori himpunan fuzzy. Pada teori himpunan fuzzy, peranan derajat keanggotaan/nilai keanggotaan sebagai penentu keberadaan elemen dalam suatu himpunan sangatlah penting (Kusumadewi \& Hartati, 2010). Fuzzy logic merupakan sebuah pendekatan untuk komputasi berdasarkan derajat kebenaran yang biasanya dinyatakan dengan benar atau salah/1 atau 0 (Sharma \& Padamwar, 2013).

Berdasarkan penjelasan tersebut, maka tujuan penelitian ini adalah untuk mengembangkan system pakar berbasis fuzzy logic untuk untuk mendiagnosa gaya belajar dominan mahasiswa. Harapan hasil penelitian dapat bermanfaat bagi lembaga dan kemajuan teknologi di masa mendatang.

\section{B. METODE PENELITIAN}

Penelitian ini menggunakan Research dan Development (R\&D) dengan menggunakan model ADDIE (Analysis, Design, Development, Implementation, Evaluation). Subjek pada penelitian ini adalah 20 (dua puluh) orang yang merupakan mahasiswa semester III Program Studi Tadris Matematika Institut Agama Islam Muhammadiyah Sinjai. Adapun rencana alur penelitian berdasarkan model pengembangan ADDIE dapat di lihat melalui alur berikut (Sugiyono, 2016):

\section{Tahap Analysis}

Pada tahap analisis, peneliti melakukan proses needs assessment (analisis kebutuhan) dan mengidentifikasi masalah (kebutuhan) melalui metode wawancara, survey/observasi dan analisis kepustakaan (hasil-hasil penelitian yang relevan).

\section{Tahap Design}

Pada tahap design, peneliti membuat rancangan (blue print) aplikasi expert system yang berbasis fuzzy logic untuk mendiagnosa gaya belajar dominan mahasiswa Tadris Matematika Institut Agama Islam Muhammadiyah (IAIM) Sinjai.

\section{Tahap Development}

Tahapan yang dilakukan dalam aplikasi expert system yang berbasis fuzzy logic untuk mendiagnosa gaya belajar dominan mahasiswa Tadris Matematika Institut Agama Islam Muhammadiyah (IAIM) Sinjai, yaitu:

\section{a. Penilaian Tim Pakar (Uji Validitas)}

Rancangan produk awal (prototype product) yang termuat dalam aplikasi yang telah di desain kemudian di ajukan kepada pakar (validator) untuk dilakukan penilaian atau validasi isi (validation content). Penilaian validator dilakukan untuk menguji validitas dari produk yang telah didesain sebelumnya. Validator melakukan penilaian dan memberikan saran/masukan untuk penyempurnaan produk. 
Masukan dan saran dari validator kemudian dijadikan bahan dalam melakukan revisi produk. Adapun formula perhitungan rerata hasil validasi sebagai berikut (Syaharuddin \& Mandailina, 2017).

$$
\bar{X}=\frac{\sum_{i=1}^{n} \bar{V}_{i}}{n}
$$

Dimana $\bar{X}$ merupakan rerata total, sedangkan $\bar{V}$ merupakan rerata tiap validator, dan $n$ adalah jumlah validator. Berikut kategori yang digunakan untuk uji validasi ahli.

Tabel 1. Kriteria Uji Validasi

\begin{tabular}{ll}
\hline \multicolumn{1}{c}{ Rata-Rata } & \multicolumn{1}{c}{ Kriteria } \\
\hline $3,5 \leq \bar{X} \leq 4$ & Sangat Valid \\
\hline $2,5 \leq \bar{X}<3,5$ & Valid \\
\hline $1,5 \leq \bar{X}<2,5$ & Cukup Valid \\
\hline $\bar{X}<1,5$ & Tidak Valid \\
\hline
\end{tabular}

\section{b. Tahap Revisi Produk/Model}

Pada tahap ini dilakukan revisi produk berdasarkan penilaian, masukan dan saran dari para validator pada tahap sebelumnya. Setelah pelaksanaan revisi dilakukan maka tahap selanjutnya adalah produk tersebut disosialisasikan (disimulasikan) kepada objek penelitian.

\section{c. Tahap sosialisasi (simulasi)}

Pada tahap ini, produk yang dihasilkan dari revisi pertama kemudian disosialisasikan (disimulasikan) kepada mahasiswa.

\section{Tahap Implementation dan Evaluation}

Pada tahap ini, dilakukan uji coba untuk melihat kepraktisan dan keefektifan aplikasi. Adapun hasil uji coba dapat dilihat langsung setelah subjek menjawab semua pertanyaan terkait gaya belajar dominannya.

\section{HASIL DAN PEMBAHASAN}

\section{Validitas Instrumen dan Aplikasi}

Sesuai dengan tahapan penelitian ini, validitas aplikasi dilakukan pada tahap development. Proses validasi dilakukan dengan menyerahkan instrumen berisi indikator serta valiadasi aplikasi yang dikembangkan. Instrumen yang disiapkan meliputi; instrumen validator ahli yang digunakan sebagai format penilaian validator dan instrumen lapangan yang digunakan sebagai alat pengumpul data lapangan.

Masing-masing validator diminta untuk menilai relevansi butir pernyataan dengan aspek dan indikator serta landasan teori yang digunakan untuk mengembangkan instrumen. Selanjutnya, validator diminta untuk memberikan nilai pada format validator yang tersedia sekaligus memberikan saran dan komentar pada naskah instrumen yang telah disediakan khusus.

Proses pengujian validitas oleh validator sebagaimana telah diuraikan pada tahap depelovment diperoleh hasil bahwa pertanyaanpertanyaan yang sesuai dengan indikator pada setiap aspek gaya belajar.

Hasil uji validitas diperoleh nilai rata-rata total validitas indikator untuk aspek visual gaya belajar sebesar $\bar{x}=3,32$. Nilai rata-rata total validitas indikator untuk aspek auditorial gaya belajar sebesar $\bar{x}=3,18$. Nilai rata-rata total validitas indikator untuk aspek kinestetik gaya belajar sebesar $\bar{x}=3,32$. Bila nilai rata-rata tersebut dikonversikan pada kriteria validitas instrumen, maka ketiga indikator tersebut termasuk kategori valid $(2,5-3,5)$.

Adapun hasil uji validasi terhadap aplikasi diperoleh hasil berupa nilai rata-rata total validitas aplikasi untuk aspek kualitas desain/tampilan sebesar $\bar{x}=3,60$, nilai rata-rata total validitas aplikasi untuk aspek kualitas tombol sebesar $\bar{x}=3,25$, dan nilai rata-rata total validitas aplikasi untuk aspek efisiensi aplikasi sebesar $\bar{x}=3,70$. Bila nilai rata-rata tersebut dikonversikan pada kriteria validitas instrumen, maka uji validasi terhadap aplikasi dan aspek kualitas tombol termasuk kategori valid $(2,5-3,5)$ sedangkan uji validitas untuk aspek efisiensi termasuk kategori sangat valid $(3,51$ 4).

Meskipun hasil aplikasi, perangkat dan instrumen pedukungnya valid, masukan dari para validator tetap dijadikan sebagai bahan masukan dan dipertimbangkan untuk menjadi dasar dalam melakukan revisi aplikasi. Perbaikan-perbaikan pada instrumen dan aplikasi berkaitan dengan aspek format validasi, dan aspek petunjuk penggunaan istrumen. Revisi untuk instrumen gaya belajar diantaranya kesesuaian antara indikator dan pertanyaan pada setiap aspek gaya belajar. 
Sedangkan untuk revisi aplikasi, disarankan untuk memperhatikan tampilan interface terutama pada tampilan warna dan background.

Hasil revisi dari berdasarkan masukan dan saran dari validator disebut sebagai revisi model kedua. Sedangkan model pertama adalah model yang di desain pada tahap design (desain). Setelah model kedua ditetapkan maka selanjutnya disosialisasikan dan disimulasikan kepada dosen-dosen lingkup Fakultas Tarbiyah dan Ilmu Keguruan Institut Agama Islam Muhammadiyah Sinjai. Sosialisasi dan simulasi ini merupakan kegiatan validasi empiris terhadap aplikasi yang dikembangkan.

Hasil dari sosialisasi dan simulasi di lingkup Fakultas Tarbiyah dan Ilmu Keguruan Institut Agama Islam Muhammadiyah Sinjai yang akan diimplementasikannya model berupa masukan dan saran dari peserta. Masukan dan saran dari peserta diantaranya pengurangan pertanyaan pada aplikasi. Hasil masukan pada kegiatan sosialisasi dan simulasi ini disebut sebagai model ketiga yang siap untuk diimplementasikan.

\section{Keefektifan Aplikasi}

Penentuan bahwa aplikasi expert system pendiagnosa gaya belajar ini efektif jika hasil persentase penilaian mahasiswa secara keseluruhan berada di atas $70 \%$.

Keefektifan aplikasi ditinjau dari penilaian mahasiswa pada tahap evaluasi menunjukkan mayoritas peserta didik merespon positif. Sebanyak 89\% mengatakan bahwa aplikasi ini efektif. Dengan demikian, jika ditinjau dari penilaian mahasiswa, aplikasi telah memenuhi kriteria efektifitas dengan kategori "sangat efektif".

Jika keefektifan ditinjau dari hasil angket penilaian mahasiswa, diperoleh nilai sangat tinggi. Sebanyak 25 (dua puluh lima) responden (mahasiswa) yang dinilai tidak ada satupun yang menunjukkan kategori rendah. Terdapat 3 (tiga) jenis karakter yang dinilai yaitu materi/pertanyaan dengan kategori "sangat tinggi", (2) komunikasi visual dengan kategori "sangat tinggi", dan (3) software dengan kategori "sangat tinggi". Dengan demikian, aplikasi expert system pendiagnosa gaya belajar ini sangat efektif.

Berdasarkan hasil dari dua indikator efektifitas di atas, maka dapat disimpulkan bahwa model pendidikan karkater berbasis budaya sekolah efektif. Kesimpulan tersebut sejalan dengan teori yang dikemukakan oleh Prasetyo bahwa uji keefektifan digunakan untuk membuktikan apakah model mampu mencapai tujuan yang telah ditetapkan atau tidak.

Berikut tampilan aplikasi expert system pendiagnosa gaya belajar yang dimaksud dalam penelitian ini:

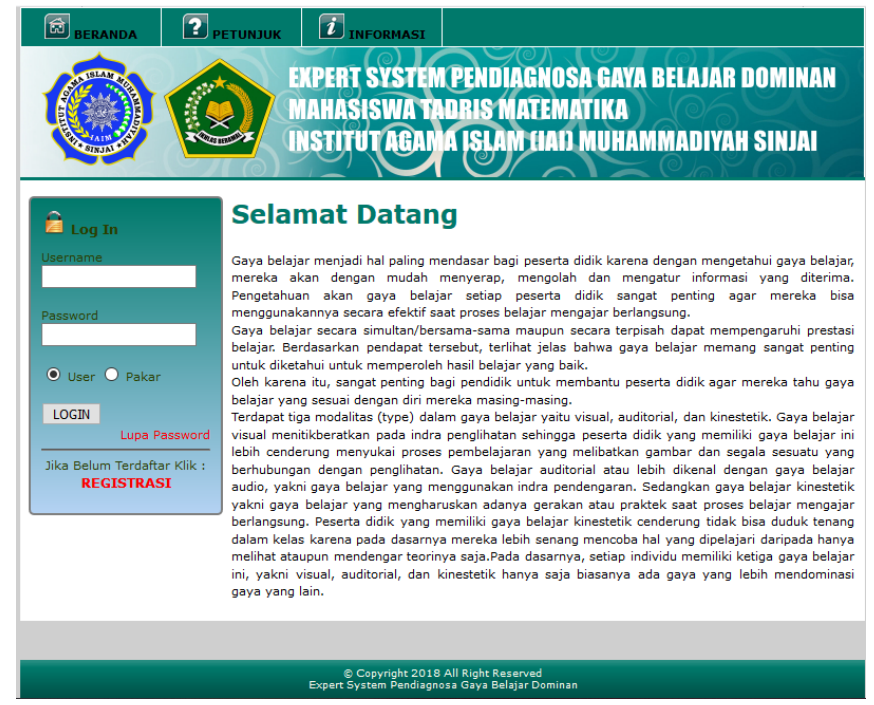

Gambar 1. Tampilan Awal Aplikasi Expert System Pendiagnosa Gaya Belajar Dominan

Beranda aplikasi ini menampilkan informasi tentang pentingnya gaya belajar serta penjelasan singkat mengenai tipe-tipe gaya belajar. Untuk memulai mendiagnosa, user harus melakukan registrasi terlebih dahulu dengan menginput username, password, biodata, pertanyaan keamanan dan verifikasi keamanan. Setelah itu, user akan mendapatkan pertanyaan-pertanyaan yang harus dijawab "ya" atau "tidak". Setelah user selesai menjawab semua pertanyaan, maka hasil diagnosa akan muncul secara otomatis. Hasil diagnosa berupa persentase gaya belajar yang dominan diantara ketiga gaya belajar tersebut.

Aplikasi ini memiliki menu bar yang terdiri dari beranda, profil, ubah password, diagnosa dan hasil diagnosa. Menu hasil diagnosa ini memungkinkan pengguna untuk melihat semua hasil diagnosa sebelumnya apabila pengguna melakukan diagnosa lebih dari satu kali.

\section{SIMPULAN DAN SARAN}

Hasil studi pendahuluan pada tahap analisis mengungkapkan bahwa aplikasi pendiagnosa gaya belajar dominan sangat dibutuhkan mahasiswa karena sebagian besar dari mereka tidak mengetahui gaya belajar mereka sendiri sehingga sulit bagi 
mereka untuk menangkap pelajaran yang diberikan oleh dosen. Aplikasi pendiagnosa gaya belajar dominan dinyatakan memenuhi kevalidan dan keefektifan. Hasil ini diperoleh setelah dilakukan uji validitas oleh para ahli yang terdiri dari validasi instrumen berupa pertanyaan tentang indikator masing-masing gaya belajar yang keseluruhan aspek berada pada kategori valid yakni 3,32 untuk aspek visual, 3,18 untuk aspek auditorial dan 3,32 untuk aspek kinestetik. Sementara untuk validasi aplikasi yang berada pada kategori sangat valid dengan nilai rata-rata validator adalah 3,52.

Aplikasi ini dikatakan efektif digunakan berdasarkan penilaian mahasiswa tentang keefesienan aplikasi, tampilan dan penggunaan bahasa yang berada pada kategori sangat efektif dengan rata-rata penilaian mahasiswa adalah 3,57 dengan persentase $89 \%$ sehingga aplikasi ini dikatakan layak digunakan untuk mendiagnosa gaya belajar dominan seseorang.

\section{UCAPAN TERIMA KASIH}

Terima kasih kepada Kementerian Agama Republik Indonesia telah memberikan kami kesempatan untuk melakukan penelitian ini. Terima kasih juga kepada sivitas akademika Institut Agama Islam Muhammadiyah Sinjai atas dukungan dan bantuannya sehingga tulisan ini dapat selesai dengan baik.

\section{REFERENSI}

Astika, R. (2018). Pengaruh Gaya Belajar Terhadap Prestasi Belajar Siswa Pada Mata Pelajaran Matematika Mi Se Kecamatan Ponggok Blitar. IAIN Tulungagung.

DePorter, B., \& Hernacki, M. (2015). Quantum Learning: Membiasakan Belajar Nyaman dan Menyenangkan. Bandung: Kaifa.

Fuad, A. J. (2016). Meta Analisis: Deferensiasi Gaya Belajar dengan Metode Pembelajaran. Journal An-Nafs: Kajian Penelitian Psikologi, 1(2), 151-165.

Hartati, L. (2013). Pengaruh Gaya Belajar dan Sikap Siswa Pada Pelajaran Matematika Terhadap Hasil Belajar Matematika. Jurnal Formatif: Jurnal Ilmiah Pendidikan MIPA, 3(3), 224-235.

Khoeron, I. R., Sumarna, N., \& Permana, T. (2016). Pengaruh Gaya Belajar Terhadap Prestasi Belajar Peserta Didik Pada Mata Pelajaran Produktif. Journal of Mechanical Engineering Education, 1(2), 291. https://doi.org/10.17509/jmee.v1i2.3816

Kusumadewi, S. ., \& Hartati, S. (2010). Neuro-Fuzzy:
Integrasi Sistem Fuzzy \& Jaringan Syaraf. yogyakarta: Graha Ilmu.

Luji Bire, A., Geradus, U., \& Bire, J. (2014). Pengaruh Gaya Belajar Visual, Auditorium, dan Kinesthetic Terhadap Prestasi Belajar Siswa SMA. Thesis, Pascasarjana Universitas Nusa Cendana.

Nurhidayah, D. A. (2015). Pengaruh Motivasi Berprestasi Dan Gaya Belajar Terhadap Prestasi Belajar Siswa Pada Mata Pelajaran Matematika SMP. Jurnal Dimensi Pendidikan Dan Pembelajaran, 3(2), 13-24. https://doi.org/10.2426/dpp.v3i2.

Rais, M. (2015). Pengaruh Penggunaan Multimedia Presentasi Kemampuan Mengingat Konsep. Jurnal Mekom Jurnal, 2(1), 10-24.

Rusman. (2012). Belajar dan Pembelajaran Berbasis Komputer. Bandung: Alfabeta. https://doi.org/10.14814/phy2.12093

Sari, A. K. (2014). Analisis Karakteristik Gaya Belajar Vak (Visual, Auditorial, Kinestetik) Mahasiswa Pendidikan. Jurnal Ilmiah Edutic, 1(1), 1-12.

Sharma, A. K. ., \& Padamwar, B. . (2013). Fuzzy logic Based Systems in Management and Bussiness Aplications. International Journal of Innovative Research in Engineering \& Science, 1(2), 1-6.

Smaldino, S. E. ., Lowther, D. L. ., \& Russel, J. D. (2013). Instructional Technology \& Media For Learning: Teknologi Pembelajaran Dan Media Untuk Belajar. Jakarta: Kencana.

Sugiyono. (2016). Metodologi Penelitian Kuantitatif, Kualitatif, dan R\&D. Bandung: Alfabeta. https://doi.org/https://doi.org/10.3929/ethz-b000238666

Syaharuddin, S., \& Mandailina, V. (2017). Pengembangan Modul Pemrograman Komputer Berbasis Matlab. JTAM (Jurnal Teori Dan Aplikasi Matematika), 1(1), 1. https://doi.org/10.31764/jtam.v1i1.1

Wahyuni, Y. (2017). Identifikasi Gaya Belajar (Visual, Auditorial, Kinestetik) Mahasiswa Pendidikan Matematika Universitas Bung Hatta. Jurnal Penelitian Dan Pembelajaran Matematika, 10(2). https://doi.org/10.30870/jppm.v10i2.2037

Widayanti, F. D. (2013). Pentingnya Mengetahui Gaya Belajar Siswa Dalam Kegiatan Pembelajaran di Kelas. Erudio Journal of Educational Innovation, 2(1). https://doi.org/10.18551/erudio.2-1.2

Yurizki, D., Halim, A., \& Melvina. (2017). Hubungan Antara Gaya Belajar Visual, Auditorial, dan Kinestetik Terhadap Hasil Belajar Fisika Pada Siswa Lab School Unsyiah. Prosiding Seminar Nasional MIPA III, 243248. 